\title{
Ben Jonson's Volpone : An Unconventional and Innovative Jacobean Comedy
}

\author{
Sajjadul Karim*
}

\begin{abstract}
Ben Jonson's Volpone (1605) is the best known, most performed and most studied of all of his Plays. Volpone, or The Fox, does not contain the traditional moral and broad themes of Shakespeare. Volpone, disguised as a didactic comedy, is actually an intelligent and cynical satire that compels the audience to rethink their moral expectations. In Volpone, Jonson was successful in combining three genres in order to create a new form of comedy. Volpone is a powerful moral study of human greed, foxy cunning, and goatish lust. It is not the traditional form of comedy. It is a play that takes on the form of a comical satire as well as a morality play. It also adapts the features of a fable, and in that it strives to teach a moral. This play puts a different twist on what people would expect from a comedy or morality play. But, more than a satire on the traditional morality, it is a satire on the type of drama that was prevalent. This article analyses how Jonson presents his audience with an unconventional way of approaching the subjects he is satirizing by creating a new form of comedy that embodies the aspects of all three genres.
\end{abstract}

Ben Jonson's Volpone has for centuries been acclaimed a masterpiece.Volpone might fairly be viewed as a turning point in Jonson's work for the public stage. Apart from depicting some of human beings' negative attributes, the play also shows the extent of human beings' compulsion to make others suffer. Jonson, however, seems to be worried here not that critics will question the unity of and between character and structure, but that they will find the plot too darkly didactic for comedy. Jonson wants his audience to see what the effect of greed has on traditional values. This drama has been a centre of discussion among the 
critics whether it is a dark comedy, comical satire on human greed, Old Comedy, beast fable, morality play or anti-Catholic discourse.

Steve Baker in his book, Picturing the Beast: Identity and Representation, analyses every character of Volpone from the perspective of animal behavior of human beings. Anne Barton gives a detailed description of his life and evaluates him as a Jacobean dramatist with especial reference to Volpone in his book Ben Jonson, Dramatist. In his book, Jonson's London and its Theatres, Martin Butler, with reference to Volpone, gives a very frightful picture of Jacobean society and the corruption that was devouring the society and its negative effect on the human mind and how the evil deeds were reflected on the stage. Alan Dessen focuses on the moral issues of Volpone in his book Jonson's Moral Comedy. Ian Donaldson gives a didactic explanation of Volpone in his book Epistle Dedicatory to Volpone. Robert Watson in his book, Ben Jonson's Parodic Strategy, shows Volpone as a parody of human greed. Ralph A. Cohen in his article "The Setting of Volpone" says that Jonson's handling of setting in Volpone is a departure from his earlier work, a departure that corresponds with and in part explains the beginning of his greatest period. P. H. Davison in his article "Volpone and the Old Comedy" says that Volpone is a comedy: but a special kind of comedy, the ultimate source of which is to be found in the Old Comedy of Greece. James D. Redwine, Jr., in his article "Volpone's 'sport' and the structure of Jonson's Volpone" wants to say, with reference to the character Mosca as 'sport', that Jonson succeeded in showing how individuals can be so possessed by their own hopes of dominating others that they resist reason or even common sense. Dorothy E. Litt in her article "Unity of Theme in Volpone" says that through the theme of self-deception Ben Jonson blotted his lines in Volpone most carefully and if the theme of selfdeception as applied here is new in critical terms, it has always been implicitly understood by audiences. Alizon Brunning's article "Jonson's Romish Foxe: Anti-Catholic Discourse in Volpone" argues that the play can also be read as an overtly Anti-Catholic discourse based around two key areas; the profanation of the Catholic sacrament of the Eucharist and the allusion to corrupt priesthood through the presentation of the bestiary fox figure. Laurence Raw's article "Revaluating Ben Jonson" investigated to demonstrate that city comedies could be made applicable to modern audiences, as long as directors were prepared to employ a degree of creative vandalism by rewriting the texts significantly, and thereby rejecting academically-inspired demands of fidelity to the text. Don Beecher's article "The Progress of Trickster in Ben Jonson's Volpone" analyses that Fox is a hero in his own world, not servant, and his tricks are the central transaction of the story and the tale of the folk trickster contains, characteristically, the waxing hero exulting in his piracy and the 
waning hero who is made to endure mortification.In his article "Tradition and Ben Jonson" L. C. Knights examines the use of literary and cultural tradition in Jonson's plays, stressing his individuality. Kathleen A. Prendergast's article "Ben Jonson Unmasked" is a study of how Ben Jonson's plays reveal Jonson's changing attitude to his fellow playwrights, the theatre as a medium, and his own role as a dramatist. Stephen Griffiths in his articles “Ben Jonson's Volpone: Black Comedy from the Dawn of the Modern Era" says that Jonson's plays challenged the audience to examine the impact of a society governed by deceit and subterfuge. The article " 'In his gold I shine' : Jacobean Comedy and the Art of the Mediating Trickster" of Alizon Brunning explores that Volpone's description of a life without labour would seem to correlate with the pre-industrial Golden Age of Ovid rather than the folk culture of Bakhtin or Locke. Clifford Davis in his article "Ben Jonson's Beastly Comedy: 'Outfoxing' the critics, 'gulling' the Audience in Volpone" says that The playwright repeatedly tantalyses the characters and the audience with the possibility of metamorphosis, but reserves the privilege for himself and thus Volpone reflects Jonson's view of the world and becomes an elaborate gulling projects design to outwit his persecutors and critics. Robert Shaughnessy in his article "Twentieth-Century Fox: Volpone's Metamorphosis" says that in performance, the play has given rise to a critical discourse of vituperation, deviance and excess which reflects the tensions and contradictions endemic to the cultural vocabulary of anthropomorphism. Richard Dutton in his article "Ben Jonson, Volpone and the Gunpowder Plot" says that Volpone was written in the wake of the Gunpowder Plot (November 1605), a resonant event in English history and one in which Ben Jonson himself was at least peripherally involved; that it is informed by the religious politics of the era, which lay behind the Plot itself and which deeply affected Jonson personally as a Roman Catholic convert in a Protestant regime. But, I have focused on the drama, as a whole, and tried to quest the innovations and the changes Jonson brought in the Jocobean theatre through Volpone.

Eagleton has suggested that Jonson's enduring appeal derives from his work's 'duality', in that it is 'learned, judicious, authoritative and neoclassical, the very type of "high" conservative art', but also 'engagingly earthy and boisterous, full of a robust "English" vitality which disdains metaphysical pretension or frigid formalism'. (p.vi) In the conventional play, Volpone would have escaped just as he did at the end of Act IV. But, instead of fitting the expectations of a comical satire, Jonson is determined to base this play on morals. Throughout the comedy, he has satirized both the conventions of his times and the lack of morals that was beginning to infect London at the time. His new form of comedy was more like the ancient fables of Aesop than a 
comedy of the Elizabethan standards. It is not exactly the traditional fable. In the traditional fable, we have a character that is similar to the witty character in a comic satire. But, in Volpone, this character is not as successful as the fable prototype.

Jonson was well acquainted with the comedies of Aristophanes. Some of the excess of Aristophanic comedy, the savageness of the satire, the farce, and the burlesque, are to be found in Volpone. But, in Jonson, one has a greater concern for moral issues than in Aristophanes. Though Jonson adapts what he takes from the Old Comedy, and is more concerned with serious issues, one can see how essential the Old Comedy relationship of Impostor and Ironical Buffoon is to the play; it is this relationship that makes clear the nature of the drama of Volpone. Volpone is a comedy, but close in tone and certain aspects of its technique to Old Comedy, the comedy of Aristophanes.

Jonson is concerned with creating a new sort of comedy. He is creating a comedy that is at the same time satirical and moral. This new sort of comedy can best be seen in the sub-plot. The sub-plot is connected with the moral aspect of the fable. It is in the subplot that we see Jonson attempting to show his audience the dangers of living like the characters of the main plot. Barish says, "It is on the thematic level that the presence of the Would-be's can be justified and their antics related to the major motifs of the play." (93) Whereas Shakespeare's seventeenth century work in comedy would turn continually toward soft edges, romance, and the pastoral, mixing both the serious and the humorous, Jonson established a reputation as one of the major social satirists of the English dramatic tradition. In fact, Jonson's comedies establish the tradition of social comedy on the English stage. In Volpone, although the satire is ultimately moral, its immediate aim is mostly social or legal.

Venice was renowned in the English mind for its excesses in wealth, in beauty, in corruption. The reputation of Venice for licentiousness was matched by its reputation for harsh justice, and the catastrophe of Volpone reflects not only Jonson's own strenuous morality but also the fame of a Venetian punishment. But, Jonson was not the first English dramatist to appreciate the aptness of Venice as a setting for a play about greed and harsh judgment. What separates the Venice of Volpone from the Venice of Shylock is Jonson's detailed depiction of that setting. Jonson clearly establishes the Venetian setting of Volpone, and preserves that setting consistently throughout. The Venice of Volpone does not grow transparent and reveal, as the play progresses, a thinly disguised London beneath an Italian setting. The Venice of Volpone is not meant to be an allegorical London. Nor has Jonson created a setting which, though true to the Italian model, is carefully 
drawn to resemble London. Venice is simply the best setting possible for the play, and throughout Volpone Jonson's steady execution of that setting shows he knew its value. The care with which Jonson draws the Venetian setting of Volpone anticipates the accuracy and technique of his finest London comedies, in spite of the fact that Jonson never visited Venice. Jonson's diligence appears in the references to currency, in allusions to literature and politics, in the language, and in the imagined topography of the play. Twelve kinds of coins are named in Volpone, and his use of six denominations of Venetian currency testifies to his careful research. Nowhere does an errant reference to English money spoil the consistency of the setting.

The most obvious way in which Jonson has matched the language of Volpone with its Venetian setting is the occasional Italian term with which he has seasoned the speech of the play's characters. Italian vocabulary that finds its way into this English play includes: sforzati, "gallie-slaves"; scartoccios, "a coffin of paper for spice"; canaglia, "raskalitie, base people, the skum of the earth"; gondole; saffi, "a catchpole, or sergeant"; clarissimo, a grandee; strappado, a Venetian torture; and Pomagnia, a popular wine in Venice. Jonson's attention to these Italian touches as well as his care in such details as literary references and coinage contributes bit by bit to the exotic and foreign atmosphere of the play as a whole. Indeed, the English subplot is itself a clever device for separating the Venetian setting from London. The very presence of two "affectate travelers" is a constant reminder that London is not the setting of the play.

Although Volpone is a richly multi-layered text which satirises greed and corruption at a general level, it can also be read as an overtly antiCatholic discourse based around two key areas: the profanation of the Catholic sacrament of the Eucharist and the allusion to corrupt priesthood through the presentation of the bestiary fox figure. The presentation of vice and corruption then acquires a resonance which links to a tradition of anti-Papist Tudor Reformation drama such as that presented by John Bale and his contemporaries who sought to play out doctrinal dispute in a dramatic arena.

The analogy between gold and the Eucharist continues throughout the play where gold is seen to have the restorative properties associated with the Eucharist in giving new life and restoring health. When Corbaccio brings Volpone a bag of coins Mosca says, "This is true physic, this your sacred medicine: / No talk of opiates to this great elixir" (I iv.71-2). Mosca then pours the coins into a bowl to minister them to Volpone, calling them "Most blessed cordial" and saying that they will "recover him" (I.iv.76-77). Later Mosca describes gold as - 
...such another medicine, it dries up

All those offensive savours! It transforms

The most deformed, and restores them lovely,

As 'twere the strange poetical girdle. (V. ii. 99-102)

The play seems to delight in mixing images of the sacred and the profane. Hedrick argues that "The topic of cannibalism illustrates in a crucial way the seriousness of the vices in Volpone. Jonson has shaped cannibalism into a sign for fundamental vice and we see that its horror is not derived from a threat to human life, but from the desire to sustain life indefinitely and infinitely and at any cost."(233) In addition to a political reading of the characters of the play, the Venice setting could be seen as significant, as Dutton points out: "Venice was the middle ground in the struggle between Protestants and Catholics in the Counter Reformation" (150).

In Volpone, we see an author who is concerned with "conveying an anatomy of the time's deformity through comedy." (Dessen 75) The deformity that Jonson is trying to comment on is the overemphasis on the importance of money. In the rape scene, we see the virtuous character of Celia crying out to God to be saved. But, unlike the morality play, it is not God who saves Celia but rather luck that has placed Bonario in a position to rescue her. But, even in the speech of Bonario when he interrupts Volpone Jonson is satirizing as well as moralizing:

Forbear, foul ravisher! libidinous swine!

Free the forced lady, or thou diest, impostor.

But that I am loath to snatch thy punishment

Out of the hand of justice, thou shouldst yet

Be made the timely sacrifice of vengeance

Before this altar, and this dross, thy idol.

Lady, let's quit this place, it is the den

Of villany. fear naught, you have a guard;

And he ere long shall meet his just reward.

(III. vii. 266-274)

In this tiny speech of Bonario, we see both the satire of conventional traditions and the vice that infects the drama Volpone. Watson says, "His speech is meant to be taken as a straight forward assertion of the play's values." (93) In his dedication Jonson makes it clear that he will deal justice out in proper manner rather than what was conventional for the theater at the time. He is trying to "disarm the moral critics of the theater" (Watson 82). 
Jonson uses the beast fable in the main plot to satirise the upside down nature of society. Watson again says:

" By having the plans of the fox fail Jonson is violating the tradition of the fable. Volpone tells them (the audience) that a strictly ethical conclusion in Jonsonian comedy will take the conventional and comfortable form . . . because the real world does not work that way, and Jonson will not yield his realism to any pleasant literary formula." (96-97)

But, this is intentional because Jonson is concerned with creating a new sort of comedy. He is creating a comedy that is at the same time satirical and moral.

In Volpone, not only is the trickster of folk lore fully accommodated to the English stage as hero, but his rising and falling destiny is redeployed in the context of an intrigue drawn from the conditions of contemporary society. Volpone behaves neither as a romantic hero nor as a tragic one despite his magnificence, the apparent depths of his motivation and his so called flaw and lamentable catastrophe. But, there is a subgenre of comedy implicit in the figure of the trickster hero with its own themes and conventions. The rise of this class of comedy is one of the salient achievements of the English theatre in the Renaissance to which there were notable contributions by several of Jonson's contemporaries. Yet, they were never able to free themselves, as Jonson did, from the established conventions preventing the trickster from arriving at his full dramatic potential. By such a measure, Volpone attains a special place in the development of intrigue comedy.

Jonson's handling of the protagonist is an innovative one. Plautus and Terence, and their followers in Renaissance Italy, offered no precedent for the trickster as hero. Volpone is, indeed, classical in its sense of economy of plot, the following of the unities and its critical attitudes towards excess in the spirit of the Roman satirists. But, there were no models among the ancients, or their Renaissance imitators, for the kind of captains of intrigue in which Jonson specialized. There is a sense in which the rise of realist satiric comedy in England was synonymous with the emancipation and diversification of the intriguer figure as internal plotter and satiric persona. Marlowe, Chapman, and Marston all laboured towards that end. But, it was Jonson who turned the comic intriguer into a self-serving knave, who driven by appetite and greed, set him up as a rich 'magnifico' and the central protagonist of the play. 
Dante's Inferno was influential on Jonson's Volpone. For one thing both works portray fraud as the root of all evil, as many other important works about morality do not. Jonson's play is quite distinctive, not following in this regard his customary Roman models, and making a special effort "to put the snaffle in their mouths, that cry out, we never punish vice in our interludes." (Donaldson 3) His moral labours in Volpone also required of him "to imitate justice, and instruct life, as well as purity of language" (Donaldson 3). Jonson's satiric conception of Venice as a locus of corruption, his cast of perverse characters, and his emphasis upon an appropriate final punishment for each of the evildoers combine to recall structural and thematic elements of Dante's work. Jonson was a dramatist always sensitive to the shaping influence of native English morality plays. All of these considerations made Dante's combination of comedy and severe morality an appealing combination to Jonson and one not easily found in most other sources available to him.

The Puritans' homophobia is also apparent in Volpone. Volpone claims that he "attracted/ The eyes and ears of all the ladies present" (III.vii.163). In another reversal of gender, Lady Would-be notices her husband with someone she believes to be a female prostitute dressed as a young man. After belittling her husband for this by calling him a client of a "female devil," she realizes her mistake and apologizes. This situation supports the possibility that Jonson believed the Puritans were making a mistake (like Lady Would-Be) in ignoring permanent, masculine reality and challenging the temporary, imaginative, and effeminate role of actors for immorality.

Morality, the main goal of the anti-theatrical movement in the Renaissance, was both supported and denounced by Jonson in various ways. However, the general perception is that Jonson, unlike Shakespeare, fueled the fires of degradation, implying that women were weak and lacked intelligence. In the annals of theatrical history, Jonson's drama could be said to perpetuate this social stereotype. Nevertheless, Jonson's crossing of the gender line and sexual scenes like Volpone's "flashing" of Celia were enough to have religious, moral, and social commentators' screaming. Barton, on the other hand, while recognizing that Volpone is not a morality play, contends that "the ending serves as just, if harsh, punishment for the dissolution of the characters"(105). Barton also points out that "the final decision rests not with the Avocatory but with the spectators of the comedy" (109).

Jonson surely wished the audience to learn from what it saw onstage. In the prologue to Volpone he asserts that the play will educate as well as entertain - 'To mix profit with your pleasure'(8). In watching actors 
imitate characters that are imitating others, the audience will leave the theatre not only entertained but also transformed by this double level of role play. Mosca's role as sycophant had been seen as the archetypal 'parasite', but in his transformation of appearance and presentation Mosca actually transforms the image of a parasite. While traditionally perceived as the stock comic and often pathetic character dependent on the rich, while actually debased, here, the role of Mosca itself takes on a new meaning: 'Almost/All the wise world is little else, in nature,/ But parasites or sub-parasites' (III. ii. 11 - 13) .

During the Renaissance, women did not participate in the theatre; hence, men, dressed in drag, played women's roles. This particular characteristic of Renaissance drama adds many dimensions, erotic and social, to the spectacle on the stage. The interactions between crossdressed boy actors and the adult male actors, by today's standards, would be considered homo-erotic. In Ben Johnson's Volpone, the role of Celia, the main female character, would have been played by a crossdressed boy; hence, many inferences about Renaissance eroticism may be made by exploring the element of cross-dressing and how it transforms the action on the stage and the audience's perception. Bonario is Celia's true love interest, which also has homosexual overtones. The sexual and intimate interactions between Celia and the male characters create an interesting dynamic. Celia was obviously made to be attractive to the male spectators, because she is the main female love interest in the play. Hence, Celia's appeal is twofold.

Volpone's anthropomorphic endowment of human figures with animal names and characteristics, in which the "metaphor of legacy hunters as carrion-eaters' is worked into "an extended beast fable in which the greedy Voltore, Corbaccio, and Corvino (vulture, raven, and crow) are outwitted by his Fox, whose willingness is inspired in part by Caxton's History of Reynard the Fox and by Aesop's fables" (Kay 89). Modifying the strategies of humours comedy by filtering them through Aesop Jonson's bestiary articulates a fierce denunciation of creatures whose greed has transformed them into something no longer fully or legitimately human. Operating within a post-Darwinian framework, critical tradition has had little difficulty moralising the play and its dramatis personae, reading the merging of the human figure with the animal as a degradation or perversion of human potential.

From another perspective, the extremity of Jonson's vision simply exemplifies early modern capitalism in action as Marx and Engels famously say that it 'has left remaining no other nexus between man and man than naked self-interest, than callous "cash payment" . . . in one word, for exploitation, veiled by religious and political illusions, it 
has substituted naked, shameless, direct, brutal exploitation'(82). Butler summarizes, Jonson is 'obsessed with situations in which business and theatre intersect . ... The plays' rogues are also their greatest entertainers, whose skills at self-enrichment cannot be disentangled from their theatrical power. .... Their theatrical abilities implicitly link their criminal gettings to the playhouses' own accumulation of profit' (28). In effect, Jonson was helping his contemporaries to internalise the ideologies of modern urban life. But, the spectator of Jonson's drama, rather than being brought face to face with sober reality, real conditions, genuine relations of production, is presented with an endless vista of surfaces, fakery and pretence. In this, the performative subjectivities of Jonsonian theatre seem particularly attuned to the milieu of late capitalism, characterized by Eagleton as 'an immense desiring machine, an enormous circuit of messages and exchanges in which pluralistic idioms proliferate and random objects, bodies, surfaces come to glow with libidinal intensity'; a scenario which is 'utopian or unthinkable, depending upon one's perspective'(394-6).

Watson views "Johnson's method in Volpone and the other comedies as a scrambling of generic plots that surprises not only the audience, but also the characters themselves. ..... The surprisingly blunt exposure and punishment in Volpone pits the indulgent conventions of satiric comedy, in which wit is the sole criterion for success, against the forces of conventional moralism"(83). His characters are human in shape, but beasts in their behaviour. The exotic city of Venice is a place of greed, lust, and corruption, where gold is indeed (as Volpone says) "the world's soul" (I.i.3). On the other hand, Baker says,

"My proposal here is that the visual image of the animal, however minimal or superficial the degree of its 'animality', invariably works as a Derridean supplement to the narrative. It is apparently exterior to that narrative, but disturbs the logic and consistency of the whole. It has the effect of bringing to light the disruptive potential of the story's animal content. It limits the extent to which the narrative can patrol and control its own boundaries".(139)

Frye has called Volpone "a kind of comic imitation of a tragedy" (70). Volpone is different from Jonson's other comedies because it straddles the boundary between comedy and tragedy, its dark tone emphasizes the playwright's desire to defy the expectations of his audience. Volpone shows the marks of Jonson's imprisonment both in his 
calculated sabotage of critical expectations and in his depiction of an immoral world inhabited by beasts. It would be simplistic, however, to interpret the play as merely a petulant manipulation of his detractors. Jonson's incarceration seems to have convinced him that local satire was too risky; as a preemptive response to further censure, the playwright retreated into the allegorical non-specificity of fables and classical allusions. Jonson clearly based his comedy on the Aesopean beast fable, "The Fox and the Grapes" and its variants, which were immensely popular during the Middle Ages and the Renaissance. The story of Chauntecleer and Pertelote, for example, in Chaucer's Nun's Priest's Tale is an imaginative retelling of this Aesopian fable.

The play is not meant to end with a proper moral and a conventional ending. Jonson uses the fifth act to approach a cynical and satirical ending mocking those of standard popular Elizabethan plays. All of the characters receive punishments fitting their crimes. Mosca is sent to the galleys as a slave, Corvino is rowed around Venice wearing ass ears, Bonario receives his father's inheritance pre-mortem, Celia is freed to go home to her father with three times her original dowry and of course Voltore is disbarred. Volpone loses everything and avarice is its own punishment, the so-called "mortifying of a Fox" (V.xii. 125). But, this moral is not easily won, nor is it left to rest at that. Jonson wants to make sure that his satire is not taken lightly. If the series of coincidences was not easy to come by, Jonson assures that the distance between audience and play would remain forever broken. Volpone makes the following speech to the audience:

The seasoning of a play is the applause.

Now, though the Fox be punish'd by the laws,

He yet doth hope there is no suff'ring due

For any fact which he hath done 'gainst you,

If there be, censure him: here he doubtful stands:

If not, fare jovially, and clap your hands.

$$
\text { (V. xii. 152-7) }
$$

Volpone speaks to the audience directly, and informs them that his punishment will not cause any suffering provided the audience shows their praise of him. This moment is both silly and brilliant for Jonson. He is aware that the audience has been there throughout the play, and that he has shown himself on the stage as much as any of the characters. The play is satirising itself as well as the didactic plays of Shakespeare and other contemporaries in the treatment of its moral. 
Marlowe, Chapman, and Marston had already supplied trickster with new guises and contemporary features, but Jonson freed him from conventional roles, from socio-moral subservience, rediscovering the dual nature of the primal folk hero. These alterations had such a powerful reorienting effect that the standard definitions of comedy must expand to accommodate them. Jonson was striking at the new spirit of acquisitiveness abroad in the Renaissance, the failing of the old feudal certainties before the rising middle-class merchants who made money and remade themselves simultaneously. And, there is a warning for the city of London in Jonson's magical, wicked picture of Venice. Jonson warns in Volpone that Londoners wishing for Venice's sophistication may have Venice's degradation as well if they do not have it already.

\section{Works Cited}

Baker, Steve. 'Picturing the Beast: Animals', Identity and Representation. Manchester: Manchester University Press, 1993.

Barish, Jonas A. Ben Jonson: A Collection of Critical Essays. Prentice-Hall Inc.: Englewood Cliffs, NJ, 1963.

Barton, Anne. Ben Jonson, Dramatist. New York, Cambridge University Press, 1984.

Butler, Martin. 'Jonson's London and its Theatres', Cambridge Companion to Ben Jonson. Cambridge: Cambridge UP, 2000.

Dessen, Alan C. Jonson's Moral Comedy. Northwestern University. Press, 1971.

Donaldson, Ian ed. "Epistle Dedicatory" to Volpone, The Oxford Authors: Ben Jonson. Oxford: Oxford University Press, 1985.

Dutton, Richard. Ben Jonson to the First Folio. Cambridge: Cambridge UP, 1983.

Eagleton, Terry. 'Preface' to Peter Womack, Ben Jonson. Oxford: Blackwell, 1986.

- - - . 'Capitalism, Modernism and Postmodernism', Modern Criticism and

Theory: A Reader. Edited by David Lodge. London: Longman, 1988.

Frye, Northrop. Anatomy of Criticism. Princeton, N.J., Princeton University press, 1971.

Hedrick, Don K. "Cooking for the Anthropology; Jonson and his audience." Studies in English Literature 17, 1977.

Kay, W. David. Ben Jonson: A Literary Life. Basingstoke: Macmillan, 1995.

Marx, Karl and Engels, Friedrich. The Communist Manifesto, edited by A. J. P. Taylor. Harmondsworth: Penguin, 1967.

Watson, Robert .Ben Jonson's Parodic Strategy. Cambridge, Mass: Harvard University Press, 1987. 